\title{
NATURAL HISTORY IN CROPS
}

\section{JIM A. WEDGWOOD, 610 Leslie Avenue, Saskatoon, Saskatchewan. S7H 2 Z2}

Assessing an insured crop for hail damage requires adjuster and farmer to walk into the field and examine the loss in detail. At such times, natural history scenes occasionally present themselves. Here are some observed while I was crop insurance adjusting from 1982 to 1988 .

Baird's Sparrows were heard in three scattered fields of wheat near Biggar on 11 July 1986. In the first instance along a back road, the pleasant, distinctive trills came from crop on one side and rank, ungrazed prairie on the other. The second and third fields were each encircled by other crops. Around Biggar this sparrow is sometimes found in patches of long grass still present on the Bear Hills' steep or stony slopes. Thus, an overflow of the birds into the crops might occur.

In 1987 the Baird's delightful tinkling again emanated from standing wheat, this time near Zealandia on 8 July, Plato and Kerrobert on the 23rd and Naicam on the 29 th, almost at the limit of the species range. They were also present in a field of rye.

The seven fields of standing spring wheat were $5 \%$ of 111 adjusted in the sparrow's range during July in 1983, 1984, 1986 and 1987. The area encompassing them angled across the province, and was delineated by the towns of Redvers, Radville, Luseland, Domremy and Naicam.

Almost all the crops would have been treated with one or more herbicides at some stage and, although a few weeds were present, all occupied fields were rated "clean" (it is now uncommon to meet a farmer who is not using herbicides).
Had breeding really occurred and, if so, was the fledging rate adequate? Alternatively, these occasions could have been displacement or post-breeding singing. Three factors aroused my suspicions: first, the late dates, although Baird's is reputedly a late nester; second, lack of thatch from the previous season - thatch, a necessity for hiding and nest building, is found naturally in long grass prairie; and third, a restricted protein base for feeding young, for indirectly some herbicides reduce the volumes of some insect species.

That these sparrows frequent wheat fields has long been known. Instances were reported by Shortt in Manitoba in 1937 and Salt in Alberta about 1965.46 Here in Saskatchewan, Callin and Belcher heard them in crops, one near Moosomin in 1945, and the other south of Regina in $1960 .{ }^{3}{ }^{2}$ Twice, the birds were in weedy grain fields. Although Salt mentions occasional nesting in weedy grain fields in Alberta, he does not specifically state that nests were actually found in these fields; the nesting may have been inferred from the presence of singing males. Lane noted that nests were not reported from the other sites named. ${ }^{4}$

At the 1987 Workshop on Endangered Species in the Prairie Provinces, Baird's Sparrow was reported to be in cultivated fields in Saskatchewan. Again there was no mention of proven breeding success. ${ }^{7}$ None too soon, the Workshop has recommended an assessment of the extent and reproductive effectiveness of the bird's use of non-native habitats.

We should have more than passing interest in this typical bird of our prairie lands. Once abundant, now rare, in my view it continues to decline. Baird's Spar- 
row is one of only a few avian species for which Saskatchewan (along with North Dakota) is the historical heartland.

Other uncommon species of birds were also heard: Le Conte's Sparrows in barley near Bruno, Sedge Wrens in wheat east of Domremy, and Sharp-tailed Sparrow in barley at Spalding. Each field contained sloughs with grassy margins, usual habitat for the three. The cropped areas, then, may have been merely extensions of their basic territories.

Common Yellowthroats and Water Pipits were unexpected frequenters of farm lands, one of standing crops, the other of swathed fields. Several Bobolinks occupied a field of canola (rapeseed) near the town of Quill Lake in July.

About 50 yards into a lentil field we flushed a dark, meadowlark-sized bird. Legs dangling, it flew about 15 yards, then dropped among the plants. "What is that? My neighbors and I have seen them in the lentils back at the home place. We don't know what they are. It's not a blackbird." Surprising were both the sight of a Sora and the farmer's remark, which indicated Soras had been seen in several lentil fields. It was 22 August in the Elrose district and there were no sloughs nearby. We could not flush the bird again. Lentils are low plants and these averaged about $14 \mathrm{in}$. (35 $\mathrm{cm})$, yet were high enough to hide the reluctant flyer. Soras become less secretive after the breeding season, and are sometimes seen away from their marshy haunts. Still, a lentil field seemed to be unusual habitat.

Among available references only an old Audubon Guide mentioned this species

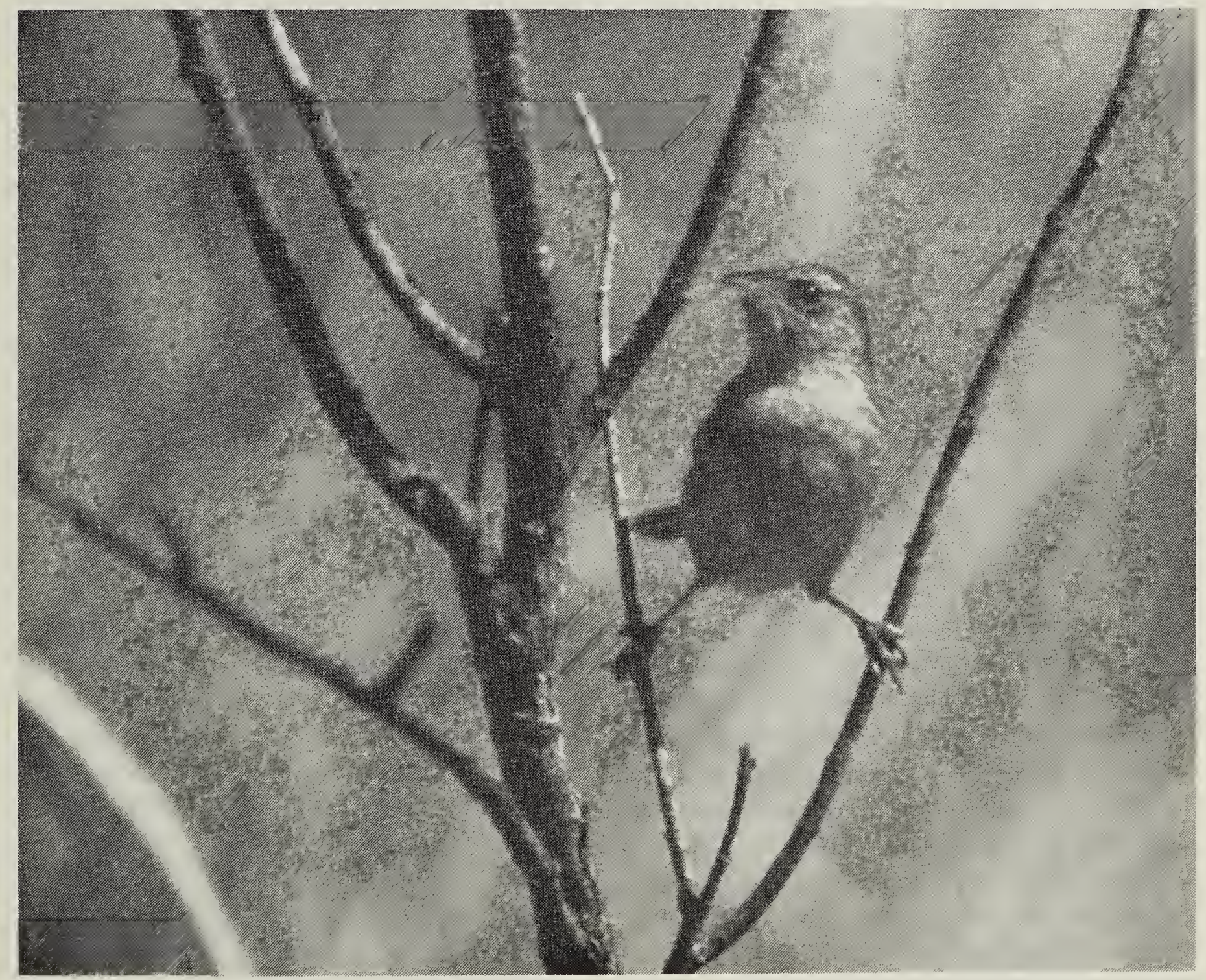


in crops: ". . . in fall the birds become seedeaters . . . inland they visit corn and grain stubble fields ..." Unknown is the extent to which Soras use lentils, a new minor crop in Saskatchewan.

In 1987 four lentil fields south of Forgan revealed a profusion of Pronghorn (Antelope) tracks. One farmer remarked that incursions by these animals had been increasing, and browsing of lentils was becoming a serious depredation problem for him and his neighbors. These plants appeared to be supplanting some of the forbs that usually make up two-thirds of the Pronghorn's diet. ${ }^{1}$

Walking through a good stand of waisthigh, tough-stemmed, densely-planted canola is most difficult and one is soon exhausted. After struggling single file 5 yards into a canola crop, we came upon a trail. Wider than our path, it angled a quarter of a mile across the field. The fresh tracks were those of Moose. And this was only $25 \mathrm{mi}$. $(40 \mathrm{~km})$ from North Battleford. The farmer had seen three of these animals in the bush beside the field when he was seeding, and later he had spotted a single moose nearby. One had to be impressed by the obvious great strength and stamina of the beast in plowing through the jungle of stems.

Finally, some observations on the aspect of natural history that brought me into these fields, hail. If the hail stones were unusually large or oddly shaped, often someone would put a sample in the freezer. They were promptly displayed upon the insurance adjuster's arrival. Twice stones formed like tambourines were exhibited: disc-shaped, with thick rings and thin centres. On a Weyburn area farm this pattern had developed further, resulting in perfect doughnuts of ice with holes clear through. A few were large, about $1.25 \mathrm{in}$. (30 mm) across. As they were collected following the storm, they likely melted somewhat before reaching the freezer. In mint condition they would have been veritable missiles.

Wicked-looking stones fell near Kipling: 0.75 in. (19 mm) across, round, but with jagged protuberances, like an ancient war club's spiked head. Teardrop-shaped hail at an Esterhazy farm and dumbbell stones - fused pairs - near Stewart Valley were also observed. Reported by farmers, but not seen by me, from the Arelee area were cigar-shaped stones about 2 in. long and near Biggar, tambourine-like pieces studded around the rims. What atmospheric conditions could have created these peculiar, uncommon, larger than usual hail stones?

Prairie croplands have been termed a biological desert. Seen from the roadside, a field may seem lifeless. Yet, as with a true desert, when one walks into it, nature may be found.

'BANFIELD, A.W.F. 1974. The mammals of Canada. Univ. of Toronto Press, Toronto.

2 BELCHER, MARGARET 1980. Birds of Regina. Sask. Natural Hist. Soc., Spec. Publ. No. 12

${ }^{3}$ CALLIN, E.M. 1980. Birds of the Qu'Appelle, 1857-1979. Sask. Natural Hist. Soc. Spec. Publ. No. 13.

${ }^{4}$ LANE, JOHN 1968. Baird's Sparrow In BENT, A.C., Ed. Life histories of North American cardinals, grosbeaks, buntings, towhees, finches, sparrows and allies. Vol. 2 Smithsonian Instit., Wash.

${ }_{5}^{5}$ POUGH, R.H. 1953. Audubon guide. All the birds of Eastern and Central North America. Doubleday and Co. Garden City, N.Y.

${ }^{6}$ SALT, W.R. and J.R. SALT 1976. The birds of Alberta. Hurtig, Edmonton.

7 WERSHLER, CLEVE 1987. Baird's Sparrow: summary of general discussion and recommendations. In HOLROYD, G.L. et al. Proceedings of the workshop on endangered species in the Prairie Provinces. Natural History Occasional Paper No. 9, Prov. Mus. of Alberta. Alberta Culture. p. 283-284 